\title{
Pentingnya Pendidikan Karakter Bagi Anak Usia Dini
}

\author{
Ayunda Zahroh Harahap
}

Prodi PIAUD, Sekolah Tinggi Agama Islam Syekh H Abdul. Halim Hasan AlIshlahiyah, Jl. Juanda, Binjai Sumatera Utara, Indonesia

Email: zahroh.ayunda@gmail.com

\begin{abstract}
Abstrak: Pendidikan karakter bertujuan untuk membentuk penyempurnaan diri individu secara terus-menerus dan melatih kemampuan diri demi menuju ke arah hidup yang lebih baik. Mengingat anak usia dini adalah golden age, maka pendidikan karakter seyogyanya ditanamkan dan diterapkan sedini mungkin. Pendidikan karakter dilaksanakan di lingkungan sekolah maupun di lingkungan rumah. Di lingkungan sekolah, guru sebagai teladan bagi anak usia dini. Sedangkan di lingkungan rumah, orang tua sebagai teladan. Jadi, harus ada keseimbangan perilaku antara guru dengan orang tua yang akan ditiru anak usia dini sebagai teladan. Periode usia dini merupakan masa yang mendasari kehidupan manusia selanjutnya. Atas dasar inilah, penting kiranya dilakukan pendidikan karakter pada anak usia dini, dalam memaksimalkan kemampuan dan potensi anak. Sebagai pendidik dan orang tua harus memanfaatkan masa golden age ini sebagai masa pembinaan, pengarahan, pembimbingan, dan pembentukkan karakter pada anak usia dini. Metode penelitian penulisan ini yang digunakan adalah kajian kepustakaan. Data-data yang dipergunakan dalam penyusunan karya tulis ini berasal dari berbagai literatur kepustakaan yang berkaitan dengan permasalahan yang dikaji. Metode penanaman karakter anak usia dini salah satunya dengan cara, keteladanan dan pembiasaan.
\end{abstract}

Kata Kunci: pendidikan, karakter, anak usia dini

\section{Pendahuluan}

Pendidikan adalah bantuan yang diberikan dengan sengaja kepada anak dalam pertumbuhan jasmani maupun rohaninya untuk mencapai tingkat dewasa. Pendidikan anak harus dimulai semenjak usia dini bahkan semenjak dalam usia kandungan, karena pertumbuhan dan perkembangan seorang anak sudah dimulai sejak prenatal, yaitu sejak dalam kandungan. Usia dini merupakan periode awal yang penting dan mendasar sepanjang dalam pertumbuhan dan perkembangan kehidupan manusia karena semua potensi anak berkembang sangat cepat pada usia tersebut.

Usia dini merupakan langkah awal untuk membentuk akhlak anak untuk mengenalkan nilai baik kepada anak supaya anak menjadi individu yang berkarakter. Anak memiliki karakteristik yang berbeda antara satu anak dengan anak lainnya, anak memiliki karakter yang unik, aktif, rasa ingin tahu, memiliki daya imajinasi yang tinggi, dan senang berteman, dan senang dengan hal-hal yang baru sehingga anak dapat tumbuh 
dan kembang dengan baik jika mendapatkan bimbingan dan kasih sayang, dari orang tua dan lingkungan sekitarnya.

Menurut undang-undang No.20 pasal 1 butir 14 tahun 2003 tentang Pendidikan Anak Usia Dini (PAUD) adalah suatu upaya pembinaan yang ditujukan kepada anak sejak lahir sampai dengan usia 6 tahun yang dilakukan melalui pemberian rangsangan pendidikan untuk membantu pertumbuhan dan perkembangan jasmani dan rohani agar anak memiliki kesiapan dalam memasuki pendidikan lebih lajut. Undang-undang No.20 tahun 2003 pasal 9 ayat 1 menegaskan setiap anak berhak memperoleh pendidikan dan pengajaran dalam rangka pengembangan pribadinya dan tingkat kecerdasannya sesuai minat dan bakatnya.

Alasan pentingnya PAUD adalah: 1) anak usia dini adalah masa peka yang memiliki perkembangan fisik, motorik, intelektual dan sosial sangat pesat, 2) tingkat variabelitas kecerdasan orang dewasa, 50\% sudah terjadi ketika masa usia dini (4 tahun pertama), $30 \%$ berikutnya pada usia 8 tahun dan $20 \%$ setelah mencapai usia 18 tahun, 3) anak usia dini berada pada masa pembentukan landasan awal bagi tumbuh dan kembang anak. Pendidikan anak usia dini (PAUD) sangat penting dilaksanakan sebagai dasar bagi pembentukan kepribadian manusia secara utuh, yaitu untuk pembentukan karakter, budi pekerti luhur, cerdas, ceria, terampil, dan bertakwa kepada Tuhan Yang Maha Esa.

Pendidikan anak usia dini dapat dimulai dari rumah atau dalam pendidikan keluarga. Berdasarkan undang-undang di atas maka pendidikan karakter sangatlah penting untuk membangun beradaban bangsa, pendidikan karakter tersebut seharusnya sudah ditanamkan sejak anak usia dini sehingga mereka sangat tepat jika dijadikan komunitas awal pembentukan karakter karena anak berada pada usia emas (golden age).

Karakter seorang individu terbentuk sejak kecil karena pengaruh genetik dan lingkungan sekitar. Proses pembentukan karakter, baik disadari maupun tidak, akan mempengaruhi cara individu tersebut memandang diri dan lingkungannya dan akan tercermin dalam perilakunya sehari-hari. Seiring dengan perkembangan zaman yang disertai dengan berkembangnya teknologi informasi telah mengakibatkan pergeseran nilai dan banyak perilaku menyimpang yang terjadi pada anak-anak, sehingga orangtua dan lembaga pendidikan serta lingkungan masyarakat perlu memberikan perhatian serius dalam membangun pendidikan karakter anak.

Melalui pendidikan karakter bukan saja dapat membuat seorang anak mempunyai akhlak yang mulia, tetapi juga dapat meningkatkan keberhasilan akademiknya. Pendidikan karakter mengajarkan kebiasaan cara berpikir dan perilaku yang membantu individu untuk hidup dan bekerja bersama sebagai keluarga, masyarakat, dan bernegara dan membantu mereka untuk membuat keputusan yang dapat dipertanggungjawabkan. 


\section{Metode}

Metode penelitian dan/atau penulisan yang digunakan adalah kajian kepustakaan. Data-data yang dipergunakan dalam penyusunan karya tulis ini berasal dari berbagai literatur kepustakaan yang berkaitan dengan permasalahan yang dikaji. Beberapa jenis referensi utama yang digunakan adalah buku, peraturan perundangan-undangan, makalah seminar, jurnal ilmiah edisi cetak maupun edisi online, hasil penelitian dan artikel ilmiah yang bersumber dari internet. Jenis data yang diperoleh variatif, bersifat kualitatif maupun kuantitatif.

Sumber data dan informasi didapatkan dari berbagai literatur dan disusun berdasarkan hasil studi dari informasi yang diperoleh. Penulisan diupayakan saling terkait antar satu sama lain dan sesuai dengan topik yang dikaji. Data yang terkumpul diseleksi dan diurutkan sesuai dengan topik kajian. Kemudian dilakukan penyusunan karya tulis berdasarkan data yang telah dipersiapkan secara logis dan sistematis. Teknik analisis data bersifat deskriptif argumentatif. Simpulan didapatkan setelah merujuk kembali pada rumusan masalah, tujuan penulisan, serta pembahasan. Adapun kesimpulan ditarik dari uraian pokok bahasan karya tulis, serta didukung dengan saran praktis sebagai rekomendasi selanjutnya.

\section{Hasil dan Diskusi}

\subsection{Definisi dan Konsep Pendidikan Karakter}

Pendidikan karakter terambil dari dua suku kata yang berbeda yaitu pendidikan dan karakter. Pendidikan lebih merujuk pada kata kerja, sedang karakter lebih pada sifatnya. Artinya, melalui proses pendidikan tersebut nantinya dapat dihasilkan sebuah karakter yang baik. Menurut Sutrisno (2011), pendidikan terjemahan dari educatio, yang kata dasarnya educate atau bahasa latinnya educo yang berati mengembangkan dari dalam; mendidik; melaksanakan hukum kegunaan.

Merujuk pada definisi di atas, pendidikan karakter pada prinsipnya adalah upaya untuk menumbuhkan kepekaan dan tanggung jawab sosial, membangun kecerdasan emosional, dan mewujudkan siswa yang memiliki etika tinggi. Orang tua kita sejak dini sudah menanamkan nilai-nilai pendidikan karakter yang menyangkut pendidikan sosial, emosional dan etika. Sebagai contoh dari kecil kita diajari berbagi makanan atau bermain, dukungan dan pujian sewaktu bangun dari jatuh adalah penguatan karakter anak. Anak dilatih untuk kekamar kecil ketika mau buang air juga merupakan pendidikan karakter yang berkait dengan etika. 
Megawangi dalam Dharma Kesuma (2011) mendefinisikan pendidikan karakter sebagai sebuah usaha untuk mendidik anak-anak agar dapat mengambil keputusan dengan bijak dan mempraktikkannya dalam kehidupan sehari-hari sehingga mereka dapat memberikan kontribusi yang positif kepada lingkungannya.

Menurut Thomas Lickona (2012), pendidikan karakter adalah usaha sengaja (sadar) untuk mewujudkan kebijakan, yaitu kualitas kemanusiaan yang baik secara objektif, bukan hanya baik untuk individu perseorangan, tetapi juga baik untuk masyarakat keseluruhan.

Dari beberapa definisi di atas dapat disimpulkan bahwa pendidikan karakter adalah usaha yang sudah tersistem, terencana dan dilakukan dengan sadar dalam upaya menanamkan dan mengembangkan nilai-nilai karakter pada peserta didik dengan melibatkan semua anggota sekolah baik kepala sekolah ataupun guru dan orang tua.

Pendidikan karakter sangat baik diajarkan pada anak sejak dini, bukan hanya ketika mereka telah dewasa. Karena pada usia dini ketika kita tanamkan karakter dengan baik dan optimal, maka akan terbentuk karakter anak yang baik ketika mereka sudah tumbuh dewasa. Pada dasarnya, tujuan utama dari pendidikan karakter ini adalah mendorong dan membentuk sifat dan perilaku anak untuk terbentuk karakter yang baik. Ketika seorang anak telah memiliki karakter yang baik, maka anak tersebut akan mampu untuk memutuskan sendiri pilihannya dan dapat bertanggung jawab atas apa yang dipilihnya. Pendidikan karakter ini dapat diberikan baik dalam wilayah formal, informal ataupun nonformal. Dalam pendidikan karakter pada anak usia dini ini memerlukan contoh sebagai modeling pada anak serta pembiasaan dalam kehidupan sehari-hari, agar kebiasaan itu dapat terus dilakukan oleh anak.

Karakter adalah sesuatu yang dipahatkan pada hati, sehingga menjadi tanda yang khas, karakter mengacu pada moralitas dalam kehidupan sehari-hari. Karakter bukan merupakan gejala sesaat, melainkan tindakan yang konsisten muncul baik secara batiniah dan rohaniah. Karakter semacam ini disebut sebagai karakter moral atau identitas moral. Karakter mengacu pada kebiasaan berpikir, berperasaan, bersikap, berbuat yang memberi bentuk tekstur dan motivasi kehidupan seseorang. Karakter bersifat jangka panjang dan konstan, berkaitan erat dengan pola tingkah laku, dan kecenderungan pribadi seseorang untuk berbuat sesuatu yang baik (Sudaryanti: 2012)

Karakter adalah serangkaian nilai yang operatif, nilai yang nyata sebagai aktualisasi dalam tindakan. Kemajuan karakter adalah pada saat suatu nilai berubah menjadi kebajikan. Kebajikan dan kemurahan adalah kecenderungan batiniah seseorang yang merespon berbagai situasi dengan cara diungkapkan dengan baik secara moral. Karakter selalu mengacu pada kebaikan yang terdiri dari tiga bagian yaitu mengetahui yang baik, menginginkan yang baik dan melakukan yang baik. Ketiga kebiasaan ini 
didasarkan pada kebiasaan pikiran, hati dan kehendak. Karakter sebagai sesuatu yang melekat pada personal yaitu totalitas ide, aspirasi, sikap yang terdapat pada individu dan telah mengkristal di dalam pikiran dan tindakan (Tan Giok Lie, 2007).

Manusia hanya dapat mengamati karakter secara eksternal dan parsial, dari kebiasan, pola pikir, pola sikap, pola tindak atau pola merespon secara emosional dan pola dalam bertingkah laku. Manusia bisa salah dalam memberikan penilaian terhadap karakter individu, hanya individu itu sendirinya yang mengetahui siapa jati dirinya.

Menurut suyanto (2009) ada 9 pilar karakter yang berasal dari nilai-nilai luhur universal, yaitu :1) karakter cinta Tuhan dan segenap ciptaan-Nya, 2) kemandirian dan tanggung jawab, 3) kejujuran/amanah, deplomatis, 4) hormat dan santun, 5) dermawan, suka tolong-menolong dan gotong royong /kerjasama, 6) percaya diri dan pekerja keras, 7) kepemimpinan dan keadilan, 8) baik dan rendah hati, 9) toleransi, kedamaian, dan kesatuan.

Menurut zulham (2010) ada 5 karakter yang harus di kembangkan yaitu: 1) trustworthy: meliputi jujur, menepati janji, memiliki loyalitas tinggi, integritas pribadi (komitmen, disiplin, selalu ingin berprestasi), 2) menghormati orang lain: perilaku untuk mementingkan kepentingan umum di atas kepentingan pribadi, siap dengan perbedaan dan tidak merasa paling benar, 3) bertanggung jawab: merupakan gabungan dari perilaku yang dapat dipertanggungjawabkannya, segala hal yang dilakukan harus berani menanggung akibatnya, berpikir sebelum bertindak, 4) adil yang meliputi: sikap terbuka, tidak memihak, mau mendengarkan orang lain dan memiliki empati, 5) cinta dan perhatian yang meliputi: menunjukkan perilaku kebaikan, hidup dengan nilai-nilai kebenaran, berbagi kebahagiaan, bersedia menolong orang lain, tidak egois, tidak kasar dan sensitif terhadap perasaan orang lain.

\subsection{Anak Usia Dini}

Usia dini merupakan masa keemasan (golden age), oleh karena itu pendidikan pada masa ini merupakan pendidikan yang sangat fundamental dan sangat menentukan perkembangan selanjutnya. Masa ini juga merupakan masa peletak dasar pertama untuk mengembangkan kemampuan kognitif, afektif, psikomotor, bahasa, sosial emosional dan moral agama pada anak. Pada masa ini anak sangat membutuhkan stimulasi dan rangsangan dari lingkungannya. Apabila anak mendapatkan stimulus yang baik, maka aspek perkembangan anak akan berkembang secara optimal (Putri R: 2015).

Anak usia dini memiliki karakteristik yang berbeda dengan orang dewasa, karena anak usia dini tumbuh dan berkembang dengan banyak cara dan berbeda. Oleh karena itu, sudah tentu kita harus mengerti dan memahami berbagai karakter dasar anak usia dini. Disebabkan karakter-karakter itulah yang akan menjadi pusat perhatian untuk dikembangkan dan diarahkan menjadi karakter positif. Pendidik perlu memahami 
karakteristik anak untuk mengoptimalkan kegiatan pembelajaran. Berikut ini beberapa karakter dasar yang dimiliki oleh anak usia dini yaitu :

a. Bekal kebaikan. Setiap anak telah dibekali oleh Tuhan Yang Maha Esa dengan bekal kebaikan dan selanjutnya lingkunganlah yang berperan aktif dalam mengarahkan serta mengembangkan bekal kebaikan.

b. Suka meniru. Anak suka menirukan gerakan serta perilaku dari orang tua serta lingkungan sekitarnya. Apa yang anak lihat senantiasa diikutinya.

c. Suka bermain. Bermain merupakan suatu kegiatan yang paling disukai oleh anak usia dini. Sebagian besar waktu anak banyak dihabiskan untuk bermain.

d. Rasa ingin tahu. Anak usia dini pada dasarnya memiliki karakter rasa ingin tahu yang tinggi, hal itu ditandai dengan anak selalu bertanya kepada siapa saja yang ia hadapi dan temui (Fadlillah: 2012).

\subsection{Pendidikan Karakter Anak Usia Dini}

Sudaryanti (2012) pembentukan karakter (character building) dapat dilakukan melalui pendidikan budi pekerti yaitu melibatkan aspek pengetahuan (cognitif), perasaan (feeling), dan tindakan (action). Abdullah Nashih Ulwan (dalam Ahmad Atabik dan Ahmad Burhanuddin, 2015) mengemukakan lima metode pendidikan, yaitu:

1. Pendidikan dengan keteladanan

Orang tua yang telah memberikan keteladanan yang baik kepada anak, tidak boleh merasa sudah menunaikan segala tanggung jawab pendidikan anaknya. Artinya keteladanan diberikan secara terus-menerus sehingga keteladanan tersebut dapat membentuk karakter anak.

2. Pendidikan dengan kebiasaan (pengulangan)

Ahmad Atabik dan Ahmad Burhanuddin (2015) dalam mendidik anak usia dini, seorang pendidik baik orang tua maupun guru, dapat meminta seorang anak kecil (anak usia dini) untuk mengulang apa yang telah dia dapatkan dari pendidik berupa praktik yang telah dilakukan bersama mereka sebelumnya. Dalam pelaksanaannya, metode pembiasaan mempunyai kelebihan serta kekurangan. Diantaranya adalah dapat menghemat tenaga dan waktu dengan baik, pembiasaan tidak hanya berkaitan dengan aspek lahirilah tetapi juga berhubungan dengan aspek batiniah, serta pembiasaan dalam sejarah tercatat sebagai metode yang berhasil dalam pembentukan kepribadian peserta didik. Sedangkan kekurangannya adalah apabila tertanam kebiasaan buruk akan sulit dihilangkan, memerlukan pengawasan serta membutuhkan stimulus atau rangsangan supaya anak dapat melakukan kebiasaan baiknya dengan istiqomah (Hadisi: 2015). 
3. Pendidikan dan nasihat

Pendidikan dan nasihat dapat diberikan melalui kegiatan bercerita. Ahmad Atabik dan Ahmad Burhanuddin (2015) metode cerita (kisah) ini sangat efektif dalam mendidik anak usia dini, sebab mereka memiliki tingkat penasaran tinggi, sehingga ketika mereka mendengar sesuatu yang baru, maka mereka akan memperhatikan dengan seksama apa yang dikisahkan oleh pendidik, dalam hal ini guru atau orang tua. Di akhir cerita seorang pendidik dapat menunjukkan hikmah di balik kisah yang baru saja diceritakan. Sehingga sejak dini mereka telah mendapatkan nilai-nilai pendidikan.

4. Pendidikan dengan memberikan perhatian dan pengawasan

Abdullah Nashih Ulwan (dalam Saifullah Kamalie dalam Ahmad Atabik dan Ahmad Burhanuddin, 2015) perhatian kepada anak dan mengontrol yang dilakukan oleh pendidik adalah asas pendidikan yang utama. Jika melihat sesuatu yang baik, dihormati, maka sang anak terus didorong untuk melakukannya. Jika melihat sesuatu yang jahat, maka harus dicegah, diberi peringatan dan dijelaskan akibatnya.

\section{Kesimpulan}

Pendidikan karakter adalah usaha yang dapat dilakukan guru atau orang tua dalam membentuk karakter anak. Pendidikan karakter sebaiknya sudah dimulai sejak usia dini. Mengingat anak usia dini adalah masa golden age, maka pada usia dinilah yang lebih tepat untuk menenamkan pendidikan karakter. Diharapkan pendidikan karakter sejak usia dini akan tertanam kuat di dalam diri anak.

Karakter yang diperkenalkan meliputi nilai-nilai universal dan nasionalisme melalui cara-cara sederhana yang mudah dilakukan anak. Mengingat anak usia dini hakikatnya sudah memiliki karakter dasar, yaitu: memiliki bekal kebaikan yang telah dianugerahkan Tuhan yang Maha Esa, suka meniru, suka bermain dan memiliki rasa ingin tahu yang tinggi.

Dari beberapa karakter dasar anak usia dini sebenarnya sudah memudahkan para pendidik dan orang tua dalam menanamkan pendidikan karakter. Ada beberapa metode pendidikan untuk menanamkan pendidikan karakter, yaitu:

1. Pendidikan dengan keteladanan. Hendaknya orang tua dan pendidik mampu sebagai suri tauladan bagi anak usia dini.

2. Pendidikan dengan kebiasaan. Sikap dan perilaku orang tua maupun guru sebagai tauladan bagi anak usia dini, dilakukan secara kontiniu sehingga menjadi kebiasaan baik untuk anak usia dini. 
3. Pendidikan dan nasihat. Bisa dilakukan dengan metode bercerita, dengan cara orang tua membacakan buku cerita ataupun dilaksanakan oleh guru di lembaga pendidikan anak usia dini.

Pendidikan dengan memberikan perhatian dan pengawasan. Dalam dunia pendidikan hendaknya orang tua dann tidak mengabaikan pemberian perhatian dan pengawasan terhadap perilaku anak usia dini.

\section{Daftar Rujukan}

Ardianto, Tuhana Taufiq, Mengembangkan Karakter Sukses Anak Era Cyber. (Yogyakarta: Ar-Ruzz Media, 2011)

Atabik, Ahmad dan Burhanuddin Ahmad, Konsep Nasih Ulwan Tentang Pendidikan

Anak. (Elementary Vol. 3 No. 2 Juli-Desember 2015)

Dharma, K., dkk., Pendidikan Karakter : Kajian Teori dan Praktik disekolah. (Bandung: Rosda Karya, 2011)

Fadlillah, Muhammad \& Khorida, Lilif Mualifatu, Pendidikan Karakter Pada Anak Usia Dini.(Yogyakarta:Ar-ruzz Media, 2012)

Hadisi, La, Pendidikan Karakter Pada Anak Usia Dini. (Jurnal Al-Ta'dib. Vol. 8 No. 2, 2015)

Istianah, Lin, Strategi Pendidikan Karakter Anak Usia Dini di Taman Kanak-Kanak Islam Terpadu (TKIT) Nurul Hidayah Sampang. (Skripsi UIN Malang, 2020)

Khaironi, Mulianah, Pendidikan Karakter Anak Usia Dini. Jurnal Golden Age (Universitas Hamzanwadi. Vol. 01 No. 2, 2012)

Lickona, Thomas, Character Matters: Persoalan Karakter. (Jakarta: Bumi Aksara, 2012)

Lie, Tan Giok, Pendidikan Dini: Pembentukan Karakter Individu. (Bandung: STT INTI, 2007) 
Putri, Ragil Dian Purnama \& Safitri, Nindiya Eka, Implementasi Nilai-Nilai Karakter KECE (Komunikatif, Empatik, Cinta Damai, Energik) Di Sekolah Dasar Dalam Pemanfaatan Bonus Demografi. (Prosiding Seminar Nasional Pendidikan, 2018)

Putri, Ragil Dian Purnama \& Kurniawan, Shopyan Jepri, Implementasi Nilai Karakter Pada Anak Usia Dini Melalui Metode Pembelajaran Field Trip. Seminar Nasional dan Call for Paper "Membangun Sinergitas Keluarga dan Sekolah Menuju PAUD Berkualitas. ISSN: 2655-6189. 2018

Silahuddin, Urgensi Membangun Karakter Anak Sejak Usia Dini. (Jurnal Pendidikan, Vol III, No 2, 2017)

Sudaryanti, Pentingnya Pendidikan Karakter Bagi Anak Usia Dini. (Jurnal Pendidikan Anak. Vol 1. Edisi 1, 2012)

Sutrisno, Pembaharuan dan Pengembangan Pendidikan Islam. (Yogyakarta :Fadilatama, 2011)

Suyanto, Slamet, Konsep Dasar Pendidikan Anak Usia Dini. Jakarta: Depdikbud, Dirjen Dikti. (Direktorat Pembinaan Tenaga Pendidikan dan Pergruan Tinggi 2005)

Suyanto, Slamet, Pendidikan Karakter Untuk Anak Usia Dini. (Jurnal Pendidikan Anak. Volume 1. Edisi 1, 2012)

Zulhan, Najib, Pendidikan Berbasis Karakter. (Surabaya: JePe Press Media Utama, 2010) 